\title{
SEPARATION OF THE VALENCE INTERMEDIATES OF HUMAN HAE- MOGLOBIN BY HIGH-PERFORMANCE CHROMATOFOCUSING
}

\author{
EZIO BOLZACCHINI* and ISABELLA FERMO \\ Istituto Scientifico San Raffaele, 20132 Milan (Italy) \\ ERMANNA ROVIDA \\ Centro di Fisiologia del Lavoro Muscolare del CNR, Milan (Italy) \\ and
}

ROBERTO COLOMBO and MICHELE SAMAJA

Dipartimento di Scienze e Tecnologie Biomediche, University of Milan, Milan (Italy)

\section{SUMMARY}

Investigations into the properties of haemoglobin often require the isolation of the valence intermediates $\left(\alpha^{\mathrm{O}}{ }_{2} \beta^{+}\right)_{2}$ and $\left(\alpha^{+} \beta^{\mathrm{O}}\right)_{2}$. Chromatofocusing with an anion-exchange gel (Mono PTM; Pharmacia, particle size $10 \mu \mathrm{m}$ ) in an HR5/20 column at various temperatures $\left(10-25^{\circ} \mathrm{C}\right)$ provides an excellent method for this task. A linearly decreasing $\mathrm{pH}$ gradient ( 8 to 7 , generated by Polybuffer 96 , Pharmacia) eluted sequentially the species methaemoglobin, $\left(\alpha^{\mathrm{O}}{ }_{2} \beta^{+}\right)_{2},\left(\alpha^{+} \beta^{\circ}\right)_{2}$ and oxygenated haemoglobin. Calibration graphs help in quantitative analyses. This method is simpler and less time consuming and provides a similar or even better resolution than the traditional ion-exchange or isoelectric focusing methods.

\section{INTRODUCTION}

When human tetrameric oxyhaemoglobin (oxyHb) is at equilibrium with an oxidant, the solution contains eight valence intermediates ${ }^{1}$. These intermediates have no free sites for ligand binding, and therefore they are stable with respect to the exchange of the ligand. However, they can quickly exchange the dimers at temperatures greater than or equal to $0^{\circ} \mathrm{C}$, and hence they can be isolated only at $-25^{\circ} \mathrm{C}$, a temperature at which the dimer exchange is virtually blocked during the time required for the separation ${ }^{1}$. Nevertheless, the symmetrical structure of two of the eight

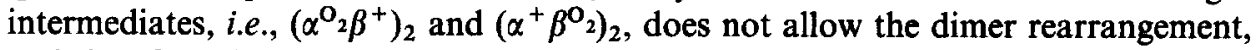
and therefore these two intermediates can be isolated and purified by ion-exchange chromatography or isoelectric focusing (IEF) at $0^{\circ} \mathrm{C}^{2}$. Consequently, these two in-

* Abbreviations used: IEF = isoelectric focusing; metHb or $\mathrm{Hb}^{+}=$methaemoglobin; oxyHb or $\mathrm{HbO}_{2}=$ oxygenated haemoglobin. The valence symmetrical intermediates of haemoglobin $\left(\alpha^{\mathrm{O}} \beta^{+}\right)_{2}$ and $\left(\alpha^{+} \beta^{\mathrm{O}_{2}}\right)_{2}$ are those intermediates with the $\alpha$ and the $\beta$ chains, respectively, bound to oxygen, and the $\beta$ and the $\alpha$ chains, respectively, in the oxidized form. 
termediates are of great interest, and have been thoroughly studied by a variety of techniques.

In this work, we tested high-performance chromatofocusing as an alternative method for isolating the valence intermediates $\left(\alpha^{\mathbf{O}_{2}} \beta^{+}\right)_{2}$ and $\left(\alpha^{+} \beta^{\mathbf{O}_{2}}\right)_{2}$ from a solution of oxyHb that was half-saturated with hexacyanoferrate(III). We found that chromatofocusing not only provides a resolution comparable to or even better than that given by ion-exchange chromatography and IEF, but that it is also simpler, less time consuming and semi-automatic.

\section{EXPERIMENTAL}

\section{Apparatus}

The chromatographic system was assembled with a P-500 pump, two V-7 valves (the volume of the injection loop was $50 \mu \mathrm{l}$ ), a flow-through pH electrode (all purchased from Pharmacia, Uppsala, Sweden) and a single-path variable-wavelength detector (Waters Assoc., Milford, MA, U.S.A.). A pre-packed ion-exchange gel column (Mono PTM, HR5/20, $200 \times 5 \mathrm{~mm}$ I.D., particle size $10 \mu \mathrm{m}$; Pharmacia) was jacketed and the temperature was maintained through an external water-circulation bath.

\section{Haemoglobin solutions}

Stock oxyHb was obtained from fresh heparinized blood by washing cells with isotonic saline, haemolysing the cells mixing them with water and carbon tetrachloride in the ratio 1:1:0.4, and filtering the solution through a Sephadex G-25 column against $0.1 M$ potassium chloride to remove organic phosphates.

Methaemoglobin (metHb) was obtained by adding solid potassium hexacyanoferrate(III) in a $20 \%$ molar excess over oxyHb haemes and incubating at $\mathrm{pH} 6.8$ at room temperature for $60 \mathrm{~min}$. Partially oxidized solutions were obtained by adding a volume of $0.1 \mathrm{M}$ potassium hexacyanoferrate(III) such that $50 \%$ of haemes were oxidized. The reaction was carried out at room temperature for $30 \mathrm{~min}$. Both solutions were then filtered through Sephadex G-25 against a $5 \mathrm{~m} M$ potassium phosphate buffer ( $\mathrm{pH} 6.7$ at room temperature). The partially oxidized solution was stored at liquid nitrogen temperature until used and was analysed within $1 \mathrm{~h}$ after thawing. The total haemoglobin concentration was measured by the Drabkin method ${ }^{3}$.

\section{Symmetrical valence intermediates}

The symmetrical valence intermediates were obtained by ion exchange ${ }^{2}$. Briefly, the partially oxidized solution was loaded on a $32 \mathrm{~cm} \times 4 \mathrm{~cm}$ I.D. CM52 (Whatman, Clifton, NJ, U.S.A.) column, previously equilibrated with $5 \mathrm{~m} M$ potassium buffer-1 $\mathrm{m} M$ EDTA (pH 6.8 at $25^{\circ} \mathrm{C}$ ). An ionic strength gradient (5 to $15 \mathrm{mM}$ potassium phosphate-1 $\mathrm{mM}$ EDTA, pH 7.5 at $25^{\circ} \mathrm{C}$ ) was then applied at a flow-rate of $60 \mathrm{ml} / \mathrm{h}$. All subsequent operations were performed at $0^{\circ} \mathrm{C}$. The purity of the intermediates, assayed by IEF at $-25^{\circ} \mathrm{C}^{1}$, was greater than $90 \%$.

\section{Chromatography}

The column was cquilibrated for 30 min with the starting buffer, usually 25 $\mathrm{m} M$ triethanolamine-hydrochloric acid $\left(\mathrm{pH} 8.0\right.$ at $\left.25^{\circ} \mathrm{C}\right)$, at a flow-rate of $60 \mathrm{ml} / \mathrm{h}$. 


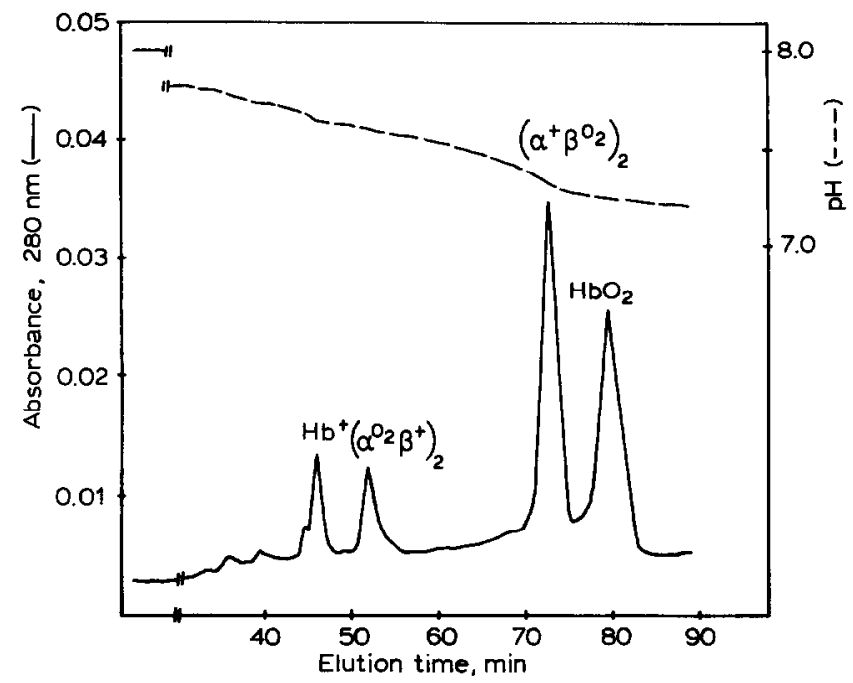

Fig. 1. Typical elution pattern for chromatofocusing of a partially oxidized haemoglobin solution ( $25 \mu \mathrm{g}$ of protein, $25^{\circ} \mathrm{C}$ ). Retention times and $\mathrm{pH}$ are given in Table $\mathrm{I}$.

The stock Polybuffer 96 (Pharmacia) was diluted 1:15 (v/v) with deionized water, titrated to $\mathrm{pH} 7.0$ at $25^{\circ} \mathrm{C}$ with $1 \mathrm{M}$ hydrochloric acid, filtered (filter pore diameter $0.45 \mu \mathrm{m})$ (Millipore, Bedford, MA, U.S.A.), and degassed under vacuum. Various amounts of protein were diluted to the final volume of $50 \mu \mathrm{l}$, filtered (filter pore diameter $0.1 \mu \mathrm{m}$ ) (Millipore), injected into the column and eluted at a constant flowrate of $20 \mathrm{ml} / \mathrm{h}$ and a constant pressure of 1.4-1.5 MPa. The elution pattern was recorded on a strip-chart recorder, and the peaks were integrated by manual graphical methods.

\section{RESULTS}

Fig. 1 and Table I show a typical elution pattern of the partially oxidized haemoglobin solution. The time required for one analysis (including the equilibration of the column) was about $2 \mathrm{~h}$. The peaks were identified by comparing their retention

TABLE I

RETENTION TIME AND ELUTION pH OF THE SYMMETRICAL VALENCE INTERMEDIATES, metHb AND oxyHb

\begin{tabular}{llll}
\hline $\begin{array}{l}\text { Haemoglobin } \\
\text { species }\end{array}$ & $\begin{array}{l}\text { Time }(\min ) \\
(\text { mean } \pm \text { S.D. })\end{array}$ & $p^{\star}$ & $p I$ \\
\hline metHb & $48.1 \pm 2.5$ & $<0.0005$ & 7.63 \\
$\left(\alpha^{\mathrm{O}} \beta^{+}\right)_{2}$ & $53.9 \pm 2.3$ & $<0.00005$ & 7.57 \\
$\left(\alpha^{+} \beta^{\mathrm{O}}\right)_{2}$ & $68.7 \pm 4.7$ & $<0.0005$ & 7.30 \\
oxyHb & $80.6 \pm 1.8$ & & 7.24 \\
\hline
\end{tabular}

* $p$ is the level of significance of the difference between two successive elution times $(n=25)$. 


\section{TABLE .II}

\section{EFFECT OF TEMPERATURE ON THE ELUTION PATTERN OF THE HAEMOGLOBIN SO- LUTION}

The same partially oxidized haemoglobin solution was eluted at three different temperatures. The values indicate the fraction of the peak area relative to the total peak area. The area of the peaks (not the concentration of the intermediates) was found to be accurate to $\pm 7.4 \%$.

\begin{tabular}{lllll}
\hline $\begin{array}{l}\text { Temperature } \\
\left({ }^{\circ} \mathrm{C}\right)\end{array}$ & metHb & $\left(\alpha^{\mathrm{O}_{2} \beta^{+}}\right)_{2}$ & $\left(\alpha^{+} \beta^{\mathrm{O}_{2}}\right)_{2}$ & oxyHb \\
\hline 10 & 0.071 & 0.059 & 0.500 & 0.370 \\
15 & 0.076 & 0.064 & 0.483 & 0.377 \\
25 & 0.074 & 0.064 & 0.513 & 0.349 \\
\hline
\end{tabular}

times with those observed after the injection of pure metHb, oxyHb and the symmetrical valence intermediates $\left(\alpha^{\mathrm{O}_{2}} \beta^{+}\right)_{2}$ and $\left(\alpha^{+} \beta^{\mathrm{O}}{ }_{2}\right)_{2}$ obtained by ion exchange. The two symmetrical intermediates were eluted in a sequence different from that observed with the ion-exchange and IEF methods, indicating an inverted $\mathrm{p} I$ value. The repeatibility of the peak areas, obtained by injecting known amounts of oxyHb, was within $\pm 7.4 \%(n=8)$. Table II shows the relative areas of the four peaks obtained from the same partially oxidized solution at three different temperatures. Fig. 2 shows the calibration graphs (amount of protein $v s$. area) of the pure symmetrical valence intermediates, metHb and oxyHb.

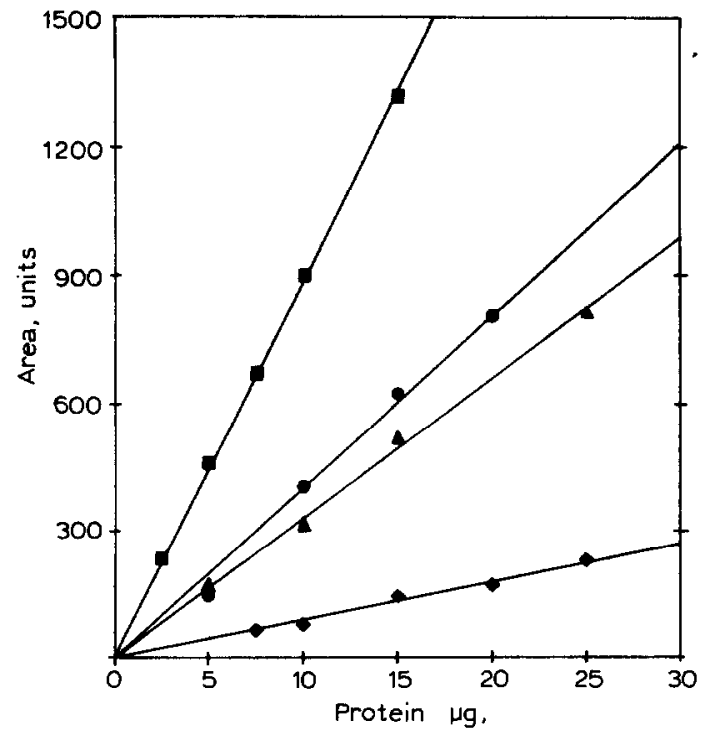

Fig. 2. Amount of protein vs. area for (from top to bottom) oxyHb (西), $\left(\alpha^{\mathrm{O}_{2} \beta^{+}}\right)_{2}(\boldsymbol{O}),\left(\alpha^{+} \beta^{\mathrm{O}}\right)_{2}(\Lambda)$ and metHb $(\diamond)$. The linear regressions of the data are shown. The correlation coefficients and the standard deviations from the means are in the ranges $0.9997-0.9973$ and $9.42-32.9$ area units, respectively. 


\section{DISCUSSION}

The main features of chromatofocusing observed in the isolation of the symmetrical valence intermediates, compared with ion-exchange chromatography and IEF at $0^{\circ} \mathrm{C}$, are speed $(<2 \mathrm{~h})$ and semi-automation. Chromatofocusing also requires less sample $(<25 \mu \mathrm{g})$ and the temperature of the column is not critical in the range $10-25^{\circ} \mathrm{C}$; these features are an advantage in routine analyses. Finally, the resolution of the peaks is much better than that obtained by the other methods.

Quantitative analyses of the symmetrical valence intermediates with our system require calibration graphs that are linear up to an amount of protein of $25 \mu \mathrm{g}$. The lines have different slopes, regardless of the wavelength, but they are reproducible. The differences in slope are attributed to some ineractions between the oxidized haemes and the column matrix. Recent work ${ }^{4}$ is consistent with this hypothesis. This interaction may also be invoked to explain the inversion of the two symmetrical valence intermediates in the elution pattern in comparison with ion-exchange chromatography and IEF. Similar $\mathrm{p} I$ shifts were also observed with mutant human haemoglobins ${ }^{5,6}$.

In conclusion, this method is a good alternative to the traditional methods of isolating the symmetrical valence intermediates, as it is faster than, and gives an accuracy comparable to, the ion-exchange and IEF methods. Chromatofocusing may be further developed to provide both a preparative chromatofocusing procedure and chromatofocusing at sub-zero temperatures or under anaerobic conditions for the analysis all the eight valence intermediates of haemoglobin.

\section{ACKNOWLEDGEMENTS}

This work was supported by Grant No. 85.00538 .04 from the Consiglio Nazionale delle Ricerche, Rome, Italy.

\section{REFERENCES}

1 M. Perrella, L. Cremonesi, L. Benazzi and L. Rossi-Bernardi, J. Biol. Chem., 256 (1981) 11098.

2 A. Tomoda and Y. Yoneyama, Anal. Biochem., 110 (1981) 431.

3 E. J. van Kampen and W. G. Zilstra, Adv. Clin. Chem., 8 (1965) 141.

4 K. Kikugawa and M. Arai, Chem. Pharm. Bull., 34 (1986) 241.

5 N. M. Alexander and W. E. Neeley, J. Chromatogr., 230 (1982) 137.

6 A. Francina, E. Dorleac, H. Cloppet and J. Delaunay, J. Chromatogr., 228 (1982) 177. 